\title{
Analyzing the Effect of Culture on Curricular Content: A Research Conception
}

\author{
Vladimir Burčik \\ Comenius University, \\ Bratislava, Slovakia
}

\author{
Frederick G. Kohun and \\ Robert Joseph Skovira \\ Robert Morris University, \\ Pittsburgh PA, USA
}

\author{
burcik@ilern.sk
}

\section{kohun@rmu.edu skovira@rmu.edu}

\begin{abstract}
A research conception is developed to enable qualitative and quantitative research on the affect of culture on the curricular content of business and information systems degree programs. The frame raises the interconnected issue of globalizing business and information systems education (theories of organization, management, and employees' motivation, and the use of information systems) and the affects of a society's culture. The paper asserts that a society's culture affects the business and information systems curricula. The essay assumes that any organization is an infoscape (an information landscape). A person's culture shapes tacitly his or her understandings of the nature and functionality of an organization and its information systems and how to manage them. The conception, following Hofstede and Hofstede, presents an understanding of the Power Distance and Uncertainty Avoidance dimensions and four organizational views: the organization as Pyramid, Market, Machine, and Family. The conception also proposes a relation of organizational type to organizational governance styles: Monarchical, Feudal, Federal, and Anarchical. Finally, the conception also includes the relationship between organizational models and styles of managing organizations: Directive, Analytic, Conceptual, and Social.
\end{abstract}

Keywords: Global business education, global information systems education, cultural impact, power distance, uncertainty avoidance, organizational theory, management theory, management style

\section{Introduction}

This paper is an expansion of a previous work (DeLorenzo et al., 2006) exploring the bridge between culture and business education. In this work, a research conception (influenced as it may be by the authors' own shared systems of meanings) is developed, based on Hofstede and Hofstede's work (2005). Its purpose is to enable qualitative and quantitative research on the claim

Material published as part of this publication, either on-line or in print, is copyrighted by the Informing Science Institute. Permission to make digital or paper copy of part or all of these works for personal or classroom use is granted without fee provided that the copies are not made or distributed for profit or commercial advantage AND that copies 1) bear this notice in full and 2) give the full citation on the first page. It is permissible to abstract these works so long as credit is given. To copy in all other cases or to republish or to post on a server or to redistribute to lists requires specific permission and payment of a fee. Contact Publisher@InformingScience.org to request redistribution permission. that a society's culture effects theories of management and organizations. People living in different societies view organizational behavior and structure differently. These views vary according to the dominance of either the power distance dimension or the uncertainty avoidance dimension. Different cultures have different models of management and ideas of the nature of organizations (Hofstede \& Hofstede, 2005). In light of 
this claim, the conception raises the issue of the effects of a society's culture on the globalization of business and information systems curricula (theories of organization, management, and information use). As Hofstede and Hofstede (2005, p. 63) write: "The authors of management books and the founders of political ideologies generate their ideas from the background of what they learned when they were growing up." Hofstede and Hofstede (2005) are skeptics about any organization's or person's ability to ignore and not be affected by the enduring and stable shared systems of meanings and values (culture) surrounding them. According to Hofstede (2001), "[n]ationality constrains rationality" (p. 381). The conception also assumes that any organization is an infoscape; a place of information flows and use. An infoscape or informational landscape is a view of an organization that envisions people, information flows, and business processes as constituting a holistic and dynamic multidimensional system (Skovira, 2004). Of course, the metaphor of an organization as an informational landscape is culturally bound.

\section{A Global Context}

In this era of extreme globalization (sometimes called the Information Age), businesses pursue strategic advantage by shifting from being multinational to being transnational organizations (Drucker, 1997; Friedman, 2000; Friedman, 2006). The idea of globalization represents an evolutionary and integrative system that pulls people and societies together into a common market of not only goods and services but also knowledge. The common backbone of this interconnectivity is the World Wide Web. Globalization enables quicker, more in-depth, more economically efficient, and more individualized access to and use of markets and knowledge. The hegemony of nation-states over their internal markets is destroyed by global competition which forces deregulation and privatization. Globalization generates a conflict-oriented tension between individuals and their societies' cultures and the shared systems of meanings inherent in the "dynamic ongoing process" of globalization (Friedman, 2000; Friedman, 2006). As Friedman (2000) writes, "...globalization has its own dominant culture, which is why it tends to be homogenizing to a certain degree" (p. 9).

Business and information system curricula must also change to face the "new world." It can be argued that business education in its attempts to make business a science, objectifies its theories and their application essentially homogenizing them. Essentially formulas of success are studied and applied in multiple formats in a variety of cultural environments with varied success. With the standardization of the MBA, for instance, through accreditation such as The Association to Advance Collegiate Schools of Business -- AACSB International the homogenization is insured without regard to when, where, how and why it is applied.

This thinking may be flawed. It can be argued that "...global business and media not only fail to homogenize the world, but the net effect of their influence may be precisely the opposite" (Hooker, 2003, p. 13). A reasonable explanation for this apparent rejection of homogeneity is the many and numerous varied cultures as contexts in which business is practiced.

This apparent rejection of homogeneity is further evidenced when “...global business and media weaken the nation state and the civic institutions it represents by making them increasingly irrelevant. More ancient forms of social organization fill the void, as nation states fracture along ethnic and religious lines." (Hooker, 2003, p. 13) There results an inherent instability with the clash between the global market influence and the cultural influences of ethnic and religious tradition, practice, and beliefs. This is evidenced throughout the world from a casual walk in London to the back streets of Ljubljana to the market places of Frienze. 


\section{Culture}

It appears, following Hofstede and Hofstede, that a person's culture, enduring and stable shared systems of meanings (Geertz, 1973; Rowe \& Mason, 1989; Trompenaars, 1994; Trompenaars \& Woolliams, 2003; Hofstede \& Hofstede, 2005), frames and shapes covertly and tacitly his or her understandings or mental models (Norman, 1988; Senge, 1990) of the nature and functionality of an organization and how to manage it (Hofstede, 2001; Hofstede \& Hofstede, 2005; Hooker, 2003). Culture is "...the collective programming of the mind that distinguishes the members of one group or category of people from others" (Hofstede \& Hofstede, 2005, p. 4). As Gannon (2001) writes: "Culture has been aptly compared to a computer program that, once activated by a few commands or stimuli, begins to operate automatically and seemingly in an independent manner..." (p. 6). These shared systems (programs) of meanings are the circumstances of a society's citizens. They are the intentional and expected ways of feeling and thinking, and speaking about things in the world. These shared systems of meanings are the silent frames of reference (Goffman, 1974) that make things sensible for each person, and for us. They are the social world, its objects and situations, habitual ways of thinking, talking, doing, and acting; they are knowledge in the world (Norman, 1988; Mead, 1994).

People act upon similar and familiar assumptions about situations, people, and things in the world and in their everyday lives. These assumptive customs are habitual frames of the emotional and cognitive modes of behavior. Culture "...is the shared ways in which groups of people understand and interpret the world" (Trompenaars, 1994, p. 3). Every social state of affairs is a transactional situation bound by unconscious norms which govern in some fashion the whys and hows of social interaction. "Culture consists of the unwritten rules of the social game" (Hofstede \& Hofstede, 2005 , p. 4). These "rules" underlie interaction. They provide the conceptual underpinnings of action (Geertz, 1973). Culture affects a manger's style of managing or decision making (Rowe \& Mason, 1989).

In examining the influence of cultural attributes on business, it is useful to use the notion of power distance and uncertainty avoidance as established by Hofstede and Hofstede (2005). This conception relies upon the correlation of the power distance and uncertainty avoidance dimensions of a culture to business and business education (Hofstede \& Hofstede, 2005; Hofstede, 2001). A society's "position" in the power distance index and uncertainty avoidance index generally posits a preferred organizational authoritative style and way of handling business processes (work flows) and information use. Hofstede and Hofstede (2005) write that “...power distance and uncertainty avoidance in particular affect our thinking about organizations" (p. 242). A large power distance culture prefers centralized authority; a strong uncertainty avoidance culture prefers structured work flows and information use. Because the power distance and uncertain avoidance indices vary from one culture to another, it would appear that business education would benefit by including these cultural dimensions as analytic tools.

\section{Power Distance}

The power distance index indicates the degree to which "...the less powerful members of institutions and organizations within a country expect and accept that power is distributed unequally." (italics in original) (Hofstede \& Hofstede, 2005, p. 46; Hofstede, 2001, p. xix; Steming \& Hammer, 1992; Mead, 1994; Dooley, 2003; Huang, Lu, \& Wong, 2003). There are three aspects of organizational living that are used to construct the power distance category of experience (Hofstede, 2001, Hofstede \& Hofstede, 2005, p. 42; Hooker, 2003, pp. 131-135).

The first aspect is about a person's perception of situations where questions are allowed or disallowed. Many supervisors and employees hold the view that being a contrarian is not being a team member; asking questions or raising issues are viewed with suspicion or hostility. A second as- 
pect concerns an employee's awareness (knowledge) of his or her superior's style of making decisions. The employee considers the supervisor to have either a directive, analytic, conceptual, or behavioral style when making decisions (Rowe \& Mason, 1989). A third aspect reflects an employee's acquiescence to, or acceptance of, as natural, the superior's way of making decisions. These aspects define and construct the power situation surrounding any employer-employee interactions. They involve a sense of personal stability in relationships.

A large power distance score suggests that there is a perception that some individuals rightfully wield more power than others. A small power distance score reflects the view that all people are of equal status, that is, in some fashion yield equal power. A large power distance index is demonstrative of centralized authority and responsibility; a small power distance index shows authority and responsibility decentralized. "Power distance helps to explain how societies regulate the behavior of their members" (Hooker, 2003, p.131). In other words, different cultures exhibit different power distance behavior. As an example, countries such as Japan exhibit a high degree of formality which reflects a higher power distance index value. In comparison, the United States tends to be more egalitarian and informal thus yielding a lower power distance index.

\section{Uncertainty Avoidance}

The uncertainty avoidance index (UAI) essentially reflects "... the extent to which the members of a culture feel threatened by ambiguous or unknown situations." (italics in original) (Hofstede \& Hofstede, 2005, p. 167; Cyert \& March, 1963/1992; Umanath \& Campbell, 1997). As Hofstede (2001) writes elsewhere, uncertainty avoidance "...is the extent to which a culture programs its members to feel either uncomfortable or comfortable in unstructured situations" (p. xix). There is a certain ambiguity in the situation or in the meanings of actions (March, 1994). There are three aspects also which determine the uncertainty avoidance category of experience (Hofstede, 1983, p. 53; Hofstede \& Hofstede, 2005, p. 166).

The first aspect is an employee's emotional perception of job distress (Hofstede, 1994b), or a sense of anxiety arising from role conflict or a lack of information or knowledge to do the job (Conor \& Worley, 1991). (The Slovaks have a word "tlak" meaning "pressure" or "tension" for this kind of situation.) A second aspect concerns a sense of well-being involved with making sure one is following the game rules, and not making any mistakes procedurally. A third aspect involves a willingness and desire to remain with a firm for the duration of one's work-life. These aspects define and construct an emotional sensibility of situational stability.

Certain cultures seem to function well and thrive under conditions of high ambiguity and uncertainty. Other cultures, on the other hand, appear to need little ambiguity and a high degree of certainty to be comfortable to perform well. Uncertainty avoidance shows up in forms of conflict, competition, or compromise (Mead, 1994). A strong uncertainty avoidance view is demonstrative of a felt need to control anxiety and situational ambiguity; a weak uncertainty avoidance view shows less of a need to control or attempt to control ambiguous situations.

\section{The Compared Societies}

The research conception begins with a curious differentiation noticed among certain societies (Hofstede, 2001; Hofstede \& Hofstede, 2005). An interesting set of relationships stands out among European Union societies (and possible future ones) and between European Union members and selected nonEuropean Union members, when one compares them along the dimensions of power distance and uncertainty avoidance (See Table 1 and Figure 1). The combination of the power distance index and the uncertainty avoidance index provide a basis for conjecture and research about the impact of culture on espoused theories of organizations, management, manage- 
rial or decision making styles, and curricula implemented across universities within these societies. "The business and business school literature often refers to national 'management' or 'leadership' cultures. Management and leadership, however, cannot be isolated from other parts of society" (Hofstede \& Hofstede, 2005, p. 20).

Table 1: PDI and UAI of Selected Countries

Source: Hofstede \& Hofstede, 2005, pp. 43-44, 168-160.

\begin{tabular}{|c|c|c|}
\hline Countries & PDI & UAI \\
\hline Australia & 36 & 51 \\
\hline Austria & 11 & 70 \\
\hline Britain & 35 & 35 \\
\hline Canada & 39 & 49 \\
\hline China & 80 & 30 \\
\hline Croatia & 73 & 80 \\
\hline Czech Rep & 57 & 74 \\
\hline France & 68 & 86 \\
\hline Germany & 35 & 65 \\
\hline Hong Kong & 68 & 29 \\
\hline Hungary & 46 & 82 \\
\hline New Zealand & 22 & 49 \\
\hline Poland & 68 & 93 \\
\hline Serbia & 86 & 92 \\
\hline Singapore & 74 & 8 \\
\hline Slovakia & 104 & 51 \\
\hline Slovenia & 71 & 88 \\
\hline Taiwan & 58 & 69 \\
\hline US & 40 & 46 \\
\hline
\end{tabular}

\begin{tabular}{|c|c|}
\hline Market & Family \\
Small-PD, Weak-UA & Large-PD, Weak-UA \\
\hline United States & Slovakia (EU) \\
China \\
Australia & Hong Kong \\
Canada & Singapore \\
New Zealand & Pyramid \\
\hline Machine & Large-PD, Strong-UA \\
Small-PD, Strong-UA & France (EU) \\
\hline Austria (EU) & Czech Republic (EU) \\
Germany (EU) & Slovenia (EU) \\
Hungary (EU) & Croatia \\
& Serbia \\
& Poland (EU) \\
& Taiwan \\
\hline
\end{tabular}

Figure 1. Societies by Organizational Model

\section{Organizational Models}

The research model presents, as one of its components, an understanding of power distance and uncertainty avoidance dimensions in relation to four models or conceptions of organizations (market, family, machine, and pyramid) definable by these dimensions. Hofstede writes (1983) "Organizations serve two main functions: distribution of power, and control of uncertainty" (p. p.64). Figure 1 shows a society's imputed organizational model as indicated by the society's

position relative to the power distance index and uncertainty avoidance index (see Table 1) (Hofstede \& Hofstede, 2005). Hofstede and Hofstede (2005) write "...that implicit models of organizations in people's minds depend primarily on the combination of power distance and uncertainty avoidance" (p. 342).

Depending upon the society, a business organization is a socially created entity (Hofstede, 1979), even when legally incorporated, having a culturally distinctive structure (see Figure 2) and can be theorized about metaphorically as a kind of Pyramid, Market, Machine, and Family (Hofstede \& Hofstede, 2005). These organizational styles are culturally bound. "Management theories have rarely recognized that these different models exist and that their occurrence is culturally determined" (Hofstede \& Hofstede, 2005, p. 58). These metaphorically named theoretical models are descriptive about the nature of the organization as well as a model about how things work organizationally (as a system). 
The metaphorical models describe a natural (i.e., in culturally acceptable manner) sensibility about the power relationships in terms of acceptance of what is deemed normal lines of authority and responsibility (March, 1994). They are descriptive about what people prefer in terms of the type of organizational structure and what they prefer about how they do their jobs. Preferred organizational structures provide taken-for-granted orderings of responsibilities and relationships (Mead, 1994). All of the views or models frame in their own manner and for their own purposes business processes or work flows and information use (Skovira, 2004). In other words, every organization has its own culture or shared systems of meanings which differentiate its members from other organizations' members (Hofstede \& Hofstede, 2005). The glue of an organization's shared systems of meanings is the "..shared perspectives of daily practices" (Hofstede \& Hofstede, 2005, p. 286). According to Hofstede and Hofstede (2005), organizational culture has six basic continuum-like dimensions. While the dimensions of power distance and uncertainty avoidance contextualize them, these dimensions frame, or form gestalts surrounding, corporate structure and functions and a person's decisions and actions. One state of affairs is a processoriented or results-oriented frame. Another state is a worker-focused (concern for the person or the social) or job-focused (things and technical affairs are valued) frame. Professional loyalty or organizational loyalty is another frame. The state of affairs dealing with system transparency or opacity is another frame. Still another is a democratic or autocratic frame. A final state of affairs is a mission-driven or policy-driven gestalt (pp. 292-296).

A market-like organization, small power distance and weak uncertainty avoidance (Hofstede \& Hofstede, 2005), (for example in the United States, Great Britain, Australia, Canada, and New Zealand) has a preference for uncentralized authority and unstructured work flows. This type of organization is usually flexible in its response to problems of production and distribution because of its decentralized nature (Hofstede, 1983). A market-like structure suggests negotiation and a certain give-and-take in decision-making situations. Independency and self-interest are perhaps basic social principles.

A family-like organization, large power distance and weak uncertainty avoidance (Hofstede \& Hofstede, 2005), (for example in Slovakia, China, Hong Kong, and Singapore) consolidates authority autocratically but does not frame business processes with a lot of rules. A family-like organizational structure is paternalistic (maternalistic) in its policies and decision-making (Hofstede $\&$ Hofstede, 2005). But e.g. in Slovakia, based on our experience, we can suppose differences between public and private sector companies. Public companies are closer to this model than private companies.

A pyramid-like organization, large power distance and strong uncertainty avoidance (Hofstede \& Hofstede, 2005), (for example in France, Czech Republic, Slovenia, Croatia, Serbia, Poland, and Taiwan) centralizes and focuses authority and prefers structured work flows (Burn et al., 1993). A pyramid-like structure of an organization represents a hierarchical organization with a built-in rigidity and reliance on policy to deal with emerging problems (Hofstede, 1983). Multiple levels of a bureaucracy slow information exchange and decision-making.

A machine-like organization, small power distance and strong uncertainty avoidance (Hofstede \& Hofstede, 2005), (for example in Germany, Austria, and Hungary) normally does not centralize authority but usually does rely on rules and procedures to structure business processes. A machine-like organizational structure is a functionally efficient organization. Policies and lines-ofcommand are in place to frame decision-making situations. It is an effective bureaucracy. 


\begin{tabular}{|c|c|}
\hline Market & Family \\
Small-PD, Weak-UA & Large-PD, Weak-UA \\
Authority not centralized & Authority centralized \\
Work flow not structured & Work flow not structured \\
Information use not structured & Information use not structured \\
\hline Machine & Pyramid \\
Small-PD, Strong-UA & Large-PD, Strong-UA \\
Authority not centralized & Authority centralized \\
Work flow structured & Work flow structured \\
Information use structured & Information use structured \\
\hline
\end{tabular}

Figure 2. Organizational Models and Aspects

\section{Organizational Governance}

A society's culture effects an organization's governance structure in terms of power distance and uncertainty avoidance (Hofstede \& Hofstede, 2005). A firm's governance structure affects the control of information and its use (Davenport, 1997). This research conception also sets out a relation of organizational type to organizational governance styles (see Figure 3). These styles are called Monarchical, Feudal, Federal, and Anarchical (Davenport, Eccles, \& Prusak, 1992; Strassman, 1995; Davenport, 1997). Organizational governance is about information control. Control of information is control of its creation, access, and use. Political frames of information use are managerial structures of informational flows for the distribution and sharing of information from a centralized to a decentralized perspective (Klein, 2002; Strassman, 1995).

The market-like organizational structure fosters federal-type organizational governance. In the federal mode of corporate governance, information control is shared across organizational boundaries of functional areas. Within this kind of political frame of information use, corporate interest groups define and interpret informational flows according to their situations (Davenport, 1997; Klein, 2002; Strassman, 1995). Indirectly, a market-like organizational structure may support anarchical-type organizational governance. In the anarchical, or adhoc, mode, control over meaning and the significance of information is personal and individualistic. There is no common sensibility of information use (Davenport, 1997; Klein, 2002; Strassman, 1995).

The family-like organizational structure fosters monarchical-type organizational governance. A monarchical governance model fits a large power distance situation (Hofstede, 2001).

The pyramid-like organization may support monarchical-type organizational governance. In the monarchical mode of corporate governance, information ownership or control is invested in one person or in one functional area of an organization. One individual designates significance and meaning of informational items and manages the interpretive models of information application (Davenport, 1997; Klein, 2002; Strassman, 1995).

The machine-like structure supports feudal-type organizational governance. The feudal mode of corporate governance suggests that the separate corporate entities control and manage their own information culture and behavior. A feudal model of organizational control is a large power distance situation (Hofstede, 2001). A senior manager is "lord of the information" (Davenport, 1997, pp. 72-74; Klein, 2002; Strassman, 1995). 


\begin{tabular}{|c|c|}
\hline Market & Family \\
Small-PD, Weak-UA & Large-PD, Weak-UA \\
Authority not centralized & Authority centralized \\
Work flow not structured & Work flow not structured \\
Information use not structured & Information use not structured \\
Governance: Federal, Anarchical & Governance: Monarchical \\
\hline Machine & Pyramid \\
Small-PD, Strong-UA & Large-PD, Strong-UA \\
Authority not centralized & Authority centralized \\
Work flow structured & Work flow structured \\
Information use structured & Information use structured \\
Governance: Feudal & Governance: Monarchical, Feudal \\
\hline
\end{tabular}

Figure 3. Organizational Governance and Organizational Models

\section{Managerial Styles}

Managing is using information and making decisions to deal with organizational uncertainty in getting things done and dealing with people (Rowe \& Mason, 1989; Simon, 1977). The conception also provides a relationship between organizational and governance models and styles of managing (making decisions for) organizations (see Figure 4). These styles are called Directive, Analytic, Conceptual, and Behavioral (hereafter Social). A managerial style or decision making style is a manager's customary and normal way of dealing with people and tasks in fulfilling organizational goals. Besides dealing with states of affairs of authority (power) and situational ambiguities (complexity), a management or decision making style is a manager's habitual manner of handling social states of affairs or technical states of affairs. A person's style underpins his or her managerial abilities (Rowe \& Mason, 1989). A managerial or decision making style is a “...predisposition for a person to think and act in a specific way in a given situation..." (Rowe \& Mason, 1989, p. 18).

A market-like organizational structure, usually a federal or adhoc orientation, seems to be supportive of analytical-style or conceptual-style managers. A family-like organization, usually a monarchical orientation, appears to be supportive of directive-style and social-style managers. A pyramid-like and machine-like organizational situation, usually a feudal or monarchical orientation, appear to be most supportive of a directive-style manager.

A manager with a directive style "...has low tolerance for ambiguity and is oriented to task and technical concerns" (Rowe \& Mason, 1989, pp. 4, 46). Directive-style managers prefer rules and procedures for dealing with most situations. But very important is their personality orientation and attitudes. They are often focuses to their dominance. It may often lead to the hostility to he others.

They like to work within goal-driven situations and are "results" oriented. Policies and formalisms are the ways of handling relationships (Rowe \& Mason, 1989). A directive managerial style is a nonparticipatory style, not readily sharing authority. The style prefers a large power distance and strong uncertainty avoidance situations (Hofstede, 2001). There is less involvement of employees in decision making in large power distance situations (Joiner, 2001). 
A manager with an analytic style "...has a high tolerance for ambiguity and is oriented to task and technical concerns" (Rowe \& Mason, 1989, pp. 4, 47). Analytical-style managers prefer to structure and organize situations, but they do like independence. While they are controllers, they prefer for themselves loose controls. They are not people friendly. They are able to deal with complex situations, sorting things out in a logical (for them) manner. They like solving complex problems in creative ways (Rowe \& Mason, 1989). An analytic management style is a nonconsultive way of handling affairs. The style prefers large power distance and weak uncertainty avoidance venues (Hofstede, 2001).

A manager with a conceptual style "...has a high tolerance for ambiguity and is oriented to people and social concerns" (Rowe \& Mason, 1989, pp. 4, 48). Conceptual-style managers gravitate toward a free-range type of organizations or open-system. They are often innovative and holistic in their approaches to organizational management, with a tendency to form consensus around endeavors (Rowe \& Mason, 1989). The style prefers a small power distance and weak uncertainty avoidance environment.

A manager with a social style "...has a low tolerance for ambiguity and is oriented to people and social concerns" (Rowe \& Mason, 1989, pp. 4, 49). Social style managers function effectively within organizations where comradeship is valued. They are creators of the good group atmosphere. Strong personalities and top achievements are often missing or leaving such group.

They prefer to work within coherent and rational settings (normative) which foster "collegial" management environments (Rowe \& Mason, 1989). The style prefers a large power distance and strong uncertainty avoidance situation.

\begin{tabular}{|c|c|}
\hline Market & Family \\
Small-PD, Weak-UA & Large-PD, Weak-UA \\
Authority not centralized & Authority centralized \\
Work flow not structured & Work flow not structured \\
Information use not structured & Information use not structured \\
Governance: Federal, Anarchical & Governance: Monarchical, Feudal \\
Managerial style: Analytical, Conceptual, & Managerial style: Directive, Social \\
Social & \\
\hline Machine & Pyramid \\
Small-PD, Strong-UA & Large-PD, Strong-UA \\
Authority not centralized & Authority centralized \\
Work flow structured & Work flow structured \\
Information use structured & Information use structured \\
Governance: Feudal & Governance: Monarchical, Feudal \\
Managerial style: Analytical, Directive & Managerial style: Directive, Analytical \\
\hline
\end{tabular}

Figure 4. Managerial Styles and Organizational models 


\section{Culturally Affected Curricula}

Accreditation organizations have their model curricula. These models are the standards for accredited programs. Standards are universalizing (if not readily globalizing) affairs by nature. What this paper suggests is that the curriculum reflects cultural patterns of the society in which it is offered. No matter how structured a curriculum may become in accord with accrediting bodies and established standards, cultural influence prevails. As an example, a German professor of management will implicitly incorporate German social constructs and culture into his/her teaching of business management, thereby, potentially altering the context of the standard. Likewise, an American professor implicitly incorporates notions of American business culture with respect to American markets in the context of an objective standard.

Business accreditation through AACSB International incorporates standards for faculty, students, curriculum, institutional support and governance - all based on the American educational model. While this provides a consistent frame or context for quality business academic programs, it done so under the guise of standardization without significant inclusion of cultural variation with respect to the socio/cultural backgrounds of the faculty, students, institutions of the countries in which the institutions reside. The presumption of achieving recognized quality academic programming is attained through standardization based on the American educational system-not through an indigenous localized educational system.

Furthermore, the recent inclusion of Eastern European countries into the European Union has complicated the issue. Those recent members of the European Union have been/are in process of migrating from a Eastern European socio/cultural/economic frame to that of a more Western European model. These countries with their associated economies and business context incorporate, to a certain degree, the international "big business" context to which accreditations like AACSB International is directed. However, these countries, like most countries of the world have a majority of business activity that is localized in predominantly small and middle sized businesses that serve the local and regional economy. The challenge is to modify global business curricula that are currently directed to big international business standardized practice to be compatible and useful for localized regional culturally framed businesses.

\section{Conclusions}

While business education currently prides itself in its attempt to incorporate global perspectives, business curricula can be argued to be, in reality, at a local level. "We have to think globally, but act locally" This is, in part, due to standardization attempts driven by accreditation i.e., AACSB International, as well political considerations i.e., EU. This standardized business education model nevertheless provides a homogenized solution in a varied and cultural driven world. The inclusion of cultural dimensions in the business education model such as Power Distance and Uncertainty Avoidance enriches the potential for successful global application and understanding.

While a case can be made for successful business practice and the teaching of such, ethnic, regional, and national cultural implications of managerial style and governance, it must be assessed and incorporated in the business practice. For instance, the use of a US or UK management textbook in a Slovenian business class does not necessarily result in Slovenian managers managing in a US or UK management style. The Slovenian managers will execute in a regionalized culturally impacted manner thus mutating the homogenized business model. If this in fact is the case, the cultural dimensions as argued by Hofstede and Hofstede should be a foundational component of the global business model. While the theories are well understood, there is a disconnect between the execution of business theory and the cultural dimension and perspective of the manager.

This paper proposes a research model for globalization of a business curriculum through the in- 
clusion of Hofstede and Hofstede's work on Power Distance and Uncertainty Avoidance. Future research is the development of a comprehensive model.

\section{References}

Burn, J., Saxena, K. B. C., Ma, L, \& Cheung, H. K. (1993). Critical issues of IS management in Hong Kong: A cultural comparison. Journal of Global Information Management, 1(4), 28-37.

Connor, P. E. \& Worley, C. H. (1991, Summer). Managing organizational stress. Business Quarterly, 56(1), 61-67.

Cyert, R. M. \& March, J. G. (1962, 1992). A behavioral theory of the firm, (2 ${ }^{\text {nd }}$ edition $)$. Cambridge, MA: Blackwell.

Davenport, T. H., Eccles, R. G., \& Prusak, L. (1992). Information politics. Sloan Management Review, $34(1), 53-65$.

Davenport, T. H. (with Prusak, L.). (1997). Information ecology: Mastering the information and knowledge environment. Boston, MA: Harvard Business School Press.

DeLorenzo, G., Kohun, F. \& Skovira, R. J. (2006). Analyzing the effect of globalizing business education on managerial and organizational theories: A framework for research. Proceedings of the $7^{\text {th }}$ International Conference of the Faculty of Management Koper, University of Primorska, Slovenia, 7, 18331840.

Dooley, R. (2003). Four cultures, one company: achieving corporate excellence through working cultural complexity. Organization Development Journal, 21(2), 52-66.

Drucker, P.F (1997). The global economy and the nation-state. Foreign Affairs, 76(5).

Friedman, T. L. (2000). The Lexus and the olive tree. New York: Farrar, Straus and Giroux.

Friedman, T. L. (2006). The world is flat: A brief history of the Twenty-first century. New York: Farrar, Straus and Giroux.

Gannon, M. J. (2001). Understanding global cultures: Metaphorical journeys through 23 nations. Thousand Oaks, CA: Sage.

Geertz, C. (1973). The interpretation of cultures. New York: Basic Books.

Goffman, E. (1974). Frame analysis: An essay on the organization of experience. Cambridge: Harvard University Press.

Hofstede, G. (Ed.). (1979). Futures for work: A book of original readings. The Hague: Matinus Nyhoff.

Hofstede, G. (1983). National cultures in four dimensions: A research-based theory of cultural differences among nations. International Studies of Management and Organizations, 13(1-2), 46-74.

Hofstede, G. (1994a). Management scientists are human. Management Science, 40(1), 4-13.

Hofstede, G. (1994b). Uncommon sense about organizations: Cases, studies, and field observations. Thousand Oaks, CA: Sage.

Hofstede, G. (2001). Culture's consequences: Comparing values, behaviors, institutions, and organizations across nations (2nd ed.). Thousand Oaks, CA: Sage.

Hofstede, G. \& Hofstede, G. J. (2005). Cultures and organizations: Software of the mind. New York: McGraw-Hill.

Hooker, J. (2003). Working across cultures. Stanford, CA: Stanford University Press.

Huang, L., Lu, M., \& Wong, B. K. (2003). The impact of power distance on email acceptance. Journal of Computer Information Systems, 44(1), 93-101.

Joiner, T. A. (2001). The influence of national culture and organizational culture alignment on job stress and performance: Evidence from Greece. Journal of Managerial Psychology, 16(3), 229-242. 
Kim, D., Pan, Y. \& Park, H. S. (1998 September). High- versus low-context cultures: A comparison of Chinese, Korean, and American cultures. Psychology \& Marketing, 15(6), 507-521.

Klein, B. D. (2002, Fall). Teaching information management to graduate non-IT majors. The Journal of Computer Information Systems, 43(1), 42-47.

Leonard, N. H., Scholl, R. W. \& Kowalski, K. B. (1999). Information processing style and decision making. Journal of Organizational Behavior, 20, 407-420.

March, J. G. \& Olsen, J. P. (1976). Ambiguity and choice in organizations. Bergen Oslo Tromso: Universitetsforlaget.

March, J. G. (with Heath, C). (1994). A primer on decision making. New York: The Free Press.

Margerison, C. J. (1974). Managerial problem solving. London: McGraw-Hill.

Mead, R. (1994). International management: Cross-cultural dimensions. Cambridge, MA: Blackwell.

Norman, D. A. (1988). The design of everyday things. New York: Currency Doubleday.

Peterson, M. F., Smith, P. B., Akande, A., Ayestaran, S., Bocher, S., Callan, V. et al. (1995 April). Role conflict, ambiguity, and overload: A 21-nation study. Academy of Management Journal, 38(2), 429452.

Raelin, J. A. (1986). The clash of cultures: Managers and professionals. Boston, MA: Harvard Business School Press.

Rowe, A. J. \& Mason, R. O. (1989). Managing with style: A guide to understanding, assessing, and improving decision making. San Francisco and London: Jossey-Bass.

Senge, P. M. (1990). The fifth discipline: The art and practice of the learning organization. New York: Currency Doubleday.

Simon, H. A. (1977). The new science of management decisions. Englewood Cliffs, NJ: Prentice-Hall.

Skovira, R. J. (2004). Using informational landscape as a model to understand information use and design within organizations. Issues in Information Systems, 1, 308-314.

Steming, B. W. \& Hammer, M. R. (1992). Cultural baggage and the adapt ion of expatriate American and Japanese managers. Management International Review 72(1), 77-89.

Strassman, P. A. (1995). The politics of information management. New Canaan, CN: The Information Economics Press.

Thatcher, J. R., Srite, M., Stepina, L. P., \& Liu, Y. (2003). Culture, overload and personal innovativeness with information technology; Extending the nomological net. The Journal of Computer Information Systems, 44(1), 74-81.

Trompenaars, F. (1994). Riding the waves of culture: Understanding diversity in global business. London: The Economist Books.

Trompenaars, F. \& Woolliams, P. (2003). Business across cultures. Chichester, England: Capstone.

Umanath, N. S. \& Campbell, T. L. (1997). Differential diffusion of information systems technology in multinational enterprises: A research model. Information Resources Management Journal, 7(1), 6-18.

\section{Biographies}

PhDr. Vladimír Burčík PhD. is Director of Academy of Communication, multimedia projects consultant at graphic studio Mr.Design. He gives lectures at the Department of Psychology at the Faculty of Arts, Comenius University, and at the Department of Design at the Faculty of Fine Arts; specialises in CI, corporate communication, human computer interaction and www design; co-author of a monograph (Internet v riadení a obchode firmy) and of a textbook (Psychodiagnostika dospelých), author of many studies and programmes on CI, published in Slovakia as well 
as abroad. He worked on creating a corporate identity for the companies Slovakofarma, Milex Schärdinger, Slovenské design centrum, Palma, Rajo, Volkswagen, Všeobecná úverová banka, Ludová banka, Západoslovenská energetika, Telenor Slovakia, Eunet, EuroTel a S\&T Slovakia. He was the member of the jury of EUROPRIX in 1999. He is a member of the Board of directors of the World Summit Award (World Summit on Information Society).

Frederick G. Kohun, Ph.D., is Associate Dean and Professor of Computer and Information Systems in the School of Communications and Information Systems at Robert Morris University in Pittsburgh, Pennsylvania. He has more that 30 years experience as a professor, department head, and academic administrator in the information systems field. He holds a bachelor degree in economics from Georgetown University, graduate degrees in economics and information science, from the University of Pittsburgh, and a Ph.D. in applied history in technology from Carnegie Mellon University. At Robert Morris University he led the design and implementation of eight technology based academic programs at the undergraduate and graduate level (including a doctoral program) as well as the attainment of ABET-CAC accreditation. He is known both nationally and internationally from his numerous publications and presentations, and active involvement as an accreditation evaluator and team leader.

Robert Joseph Skovira, Ph.D., is a Professor of Computer and Information Systems in the Department of Computer and Information Systems, School of Communications and Information Systems, at Robert Morris University, Pittsburgh PA USA. He teaches undergraduate and graduate (MS) courses including Java Programming, Secure Programming, Knowledge Management, Global, Economic, Social, and Ethical Issues of Computing, Decision Support Systems, Information Design, and Ethical and Legal Issues of Technology. In the Doctor of Science program he teaches Ethnography of Information Systems. He was a visiting professor at Comenius University, Bratislava, Slovakia, in 1997 and 2006. Dr. Skovira's research interests include information and information system use within organizations (politics of information, information system bias, secure programming), cultural and moral frameworks, decision making and knowledge mapping, and information design and thinking visually. 